ISSN 0103-5150

Fisioter. Mov., Curitiba, v. 29, n. 3, p. 507-514, Jul./Set. 2016

Licenciado sob uma Licença Creative Commons

DOI: http://dx.doi.org.10.1590/1980-5918.029.003.A008

\title{
Effect of a physical therapy protocol on the health related quality of life of patients with temporomandibular disorder
}

\author{
Efeitos da fisioterapia na qualidade de vida de \\ pacientes com disfunção temporomandibular
}

\author{
Maíra de Oliveira Viana ${ }^{[a, b]}$, Natália Bitar da Cunha Olegario ${ }^{[b]}$, \\ Mariana de Oliveira Viana ${ }^{[c]}$, Guilherme Pinheiro Ferreira da Silva ${ }^{[b]}$, Jair Licio Ferreira Santos ${ }^{[a]}$, \\ Sarah Tarcisia Rebelo Ferreira de Carvalho ${ }^{[\mathrm{d}]^{*}}$ \\ [a] Universidade de São Paulo, Faculdade de Medicina de Ribeirão Preto (FMRP), Ribeirão Preto, SP, Brazil \\ [b] Universidade de Fortaleza (UNIFOR), Fortaleza, CE, Brazil \\ [c] Universidade Federal do Ceará (UFC), Fortaleza, CE, Brazil \\ [d] Universidade Ceuma (UNICEUMA), São Luís, MA, Brazil
}

\begin{abstract}
Introduction: Temporomandibular disorders (TMD) comprise a group of diseases that affect not only the temporomandibular joint, but also different areas extrinsic to the joints. Quality of life has been the subject of numerous studies in the Health area, especially aimed at people with chronic diseases, such as TMD. Objective: To evaluate effects of a physical therapy protocol on the quality of life of patients with temporomandibular disorder. Methods: Blinded, prospective, clinical trial, with 60 patients of both genders, aged between 18 and 70 years with TMD diagnosis attended in the clinic of Ribeirão Preto School of Dentistry. The patients were
\end{abstract}

*MOV: MS, e-mail: maira.ov@gmail.com NBCO: MS, e-mail: nath_bitar@hotmail.com

MOV: MS, Doctoral Student, e-mail: marys.viana@gmail.com

GPFS: MS, Doctoral Student, e-mail: guilhermepinheiro87@hotmail.com

JLFS: PhD, e-mail: jalifesa@usp.br

STRFC: PhD, e-mail: sarahtrfc@hotmail.com 
divided into two groups, with one group, in addition to dental treatment, receiving a physical therapy protocol and the other group dental treatment only, for 5 weeks. The measurement of quality of life was obtained through the generic SF-36 questionnaire, at the beginning and end of the proposed protocol. Results: The patients to whom the physical therapy protocol was applied associated with dental care presented increased scores in all the domains of the questionnaire. In the group that received only dental treatment, improvements were only found in the domain related to pain. Conclusion: The application of a physical therapy protocol was able to improve the quality of life of patients with temporomandibular disorder.

Keywords: Quality of Life. Physical Therapy Modalities. Temporomandibular Joint Disorders.

\section{Resumo}

Introdução: A disfunção temporomandibular (DTM) compõem um conjunto de doenças que afetam não somente a articulação Temporomandibular, mas também diferentes áreas extrínsecas às articulações. A qualidade de vida tem sido motivo de inúmeros estudos na área da saúde, especialmente voltados para pessoas com doenças crônicas, como a DTM. Objetivo: Avaliar efeitos de um protocolo fisioterapêutico na qualidade de vida de pacientes com disfunção temporomandibular. Métodos: Estudo do tipo ensaio clínico, cego e prospectivo, com 60 pacientes de ambos os sexos, com idade variando entre 18 a 70 anos com diagnóstico de DTM atendidos na clínica da Faculdade de Odontologia de Ribeirão Preto. Os pacientes foram divididos em dois grupos, em um grupo, além do acompanhamento odontológico, foi aplicado um protocolo fisioterapêutico e no outro grupo foi realizado apenas o acompanhamento odontológico, durante 5 semanas. A mensuração da qualidade de vida foi obtida pelo questionário genérico SF-36, no início e final do protocolo proposto. Resultados: Nos pacientes em que foi aplicado o protocolo fisioterapêutico associado ao acompanhamento odontológico apresentaram escores mais elevados em todos os domínios do questionário. No grupo que recebeu apenas acompanhamento odontológico, verificou-se melhora apenas no domínio relacionado a dor. Conclusão: A aplicação de um protocolo fisioterapêutico foi capaz de melhorar a qualidade de vida de pacientes com disfunção temporomandibular.

Palavras-chave: Qualidade de vida. Modalidades de Fisioterapia. Transtornos da Articulação Temporomandibular.

\section{Introduction}

In recent years temporomandibular disorders (TMD) have become a widely known and discussed concept, mainly among health professionals, including physicians, dentists, speech therapists, psychologists and physical therapists (1).

Temporomandibular disorders, also known as craniomandibular disorders, comprise a group of diseases that affect not only the temporomandibular joint (TMJ), but also different areas extrinsic to the joints (2). Their etiology is multifactorial and related to emotional stress, to occlusal interferences, to tooth loss or bad position of the teeth, to postural changes, to disorder of the masticatory and adjacent muscles, to the extrinsic and intrinsic changes of the structural components of the TMJ or even to a combination all these factors $(3,4,5)$.
Among the various manifestations, the following can be cited as the classic symptoms of TMD: noises in the jaw joint (crackles or clicks); mandibular hypomobility, headache, pain in the TMJ, earache and/ or tinnitus, asymmetries, irregularities, limitations and/or deviations in movements of the jaw, sleep disorders and change in head position $(1,6,7,8,9)$.

The authors of the American Academy of Craniomandibular Disorders (AACD) confirm that physical therapy helps with the relief of musculoskeletal pain and the restoration of normal function through changing the sensory input and reducing inflammation, decreasing, coordinating and strengthening the muscular activity, and promoting repair and regeneration of the tissues (10).

There is evidence that TMD and other painful conditions of the face cause an impact on the quality of life (QoL), however, only a small number of studies 
document the use of specific questionnaires or multidimensional tools for this purpose (3).

Quality of life is a broad, subjective, productive and polysemic concept which has been the subject of numerous studies in the Health area, especially directed towards people with chronic diseases, such as TMD. It is defined by the individual as an internal experience of satisfaction and well-being in their living process $(11,12)$.

Given the complexity of the symptoms and their consequences, studies indicate that TMJ disorders require broad multidisciplinary care, with physical therapy having a vital role in the rehabilitation of these patients, since it provides pain relief, rehabilitates the neuromuscular system and restores the mandibular rest position and muscle coordination, therefore improving quality of life $(7,10,13)$.

In this context, the aim of this study was to evaluate the effect of a physical therapy protocol on the QoL of patients with TMD.

\section{Methods}

A blinded, prospective, clinical trial was conducted, in the Odontology service of the Ribeirão Preto School of Dentistry - Universidade de São Paulo (FORP-USP), from May to September 2008.

This study followed the ethical and legal principles, in accordance with the recommendations of Resolution No. 196/96 of the CNS, which sets out the principles for human research (14), and was approved by the Research Ethics Committee of the University of São Paulo under authorization number 2007.1.1266.58.4. All the patients agreed to participate in the study by signing the informed consent form.

The sample consisted of 60 patients with clinical diagnosis of TMD of muscular and/or joint origin, of both genders, aged $18-70$ years registered in the Odontology service of FORP-USP. The patients were diagnosed and referred by surgical dentists of the Occlusion, Temporomandibular Disorder and Orofacial Pain Clinic as patients with special needs: multidisciplinary approach.

The exclusion criterion used were patients undergoing other treatments in the previous month, patients with a history of traumatic injury or surgical treatment in the orofacial region or carriers of systemic, degenerative and/or neoplastic diseases. All the patients needed to have time available to attend the ten physical therapy sessions and the necessary dental consultations.

The study participants were divided into two groups, the experimental group: composed of patients with TMD that received dental treatment and physical therapy $(\mathrm{n}=30)$; and the control group: TMD patients who received dental treatment but no receive physical therapy $(n=30)$. The allocation of participants was made by convenience.

An instrument to assess quality of life, validated for the Brazilian population, the SF-36 Medical Outcome Study-MOS Short Form Health Survey (15) was applied before and five weeks after the protocol used in this study. When the patient did not present conditions to complete the instrument, in the case of illiteracy, change in cognition or low educational level, the instrument was applied by the researcher, without inducing any responses.

The SF-36 is a generic instrument composed of 11 questions and divided into eight domains: functional capacity, limitations due to physical aspects, pain, general health status, vitality, social aspects, emotional aspects, and mental health, with these dimensions representing basic human values relevant to the assessment of the quality of life of the general population. The scores of the quality of life dimensions, classified in this instrument, range from zero, poorest health status, to 100 , best possible health status.

The dental treatment consisted of weekly consultations in which, according to the clinical condition of the patient, occlusal adjustments and preparation of myorelaxing plates were performed.

The physical therapy treatment protocol received by the experimental group was performed twice weekly for a total of ten sessions, with an average duration of 50 minutes each. The protocol employed was initiated with the application of the Bioset brand ultrasound in each temporomandibular joint separately, using continuous handling parameters, frequency of $3 \mathrm{MHz}$, intensity of $0.6 \mathrm{~W} / \mathrm{cm}^{2}$, for 3 minutes (16). Next, joint mobilization; pompage preparatory maneuvers in the cervical spine for the purpose of lengthening the anterior and posterior muscles of the cervical spine; and active kinesiotherapy for the movements of the TMJ and cervical spine were performed (17).

The Joint mobilization was carried out based on the description of Schmitt and Gerrits $(18,19)$, through the intraoral articular distraction technique applied rhythmically. In this, the thumb of the therapist rests on the occlusal surfaces of the lower molars, while 
Viana M0, Olegario NBC, Viana MO, Silva GPF, Santos JLF, Carvalho STRF.

the other fingers are held under the chin, in order to perform traction movements (down and forward) and condylar translation (backward and forward).

After the data collection, the results were presented as the medians, since the measure was a score type. The comparisons of the SF-36 scores in each group wereperformed through non-parametric statistics, using the Wilcoxon test (20), with the probability of the occurrence of type 1 error fixed at $5 \%$, using the statistical program Stata version 10.0.

Table 1 - Distribution of the individuals with Temporomandibular Disorders, according to gender and age group in the group that received physical therapy and dental treatment, Ribeirão Preto - SP, 2008

\begin{tabular}{|c|c|c|c|c|c|c|c|}
\hline \multirow{3}{*}{ Group } & \multirow{3}{*}{$\begin{array}{c}\text { Age } \\
\text { (years) }\end{array}$} & \multicolumn{4}{|c|}{ Gender } & \multirow{2}{*}{\multicolumn{2}{|c|}{ Total }} \\
\hline & & \multicolumn{2}{|c|}{ Female } & \multicolumn{2}{|c|}{ Male } & & \\
\hline & & $\mathrm{n}$ & $\%$ & $\mathrm{n}$ & $\%$ & $\mathrm{n}$ & $\%$ \\
\hline \multirow{6}{*}{ Experimental } & 18 to 24 & 3 & 13.64 & 1 & 12.50 & 4 & 13.33 \\
\hline & 25 to 34 & 4 & 18.18 & 1 & 12.50 & 5 & 16.67 \\
\hline & 35 to 44 & 5 & 22.73 & 1 & 12.50 & 6 & 20.00 \\
\hline & 45 to 54 & 2 & 9.09 & 2 & 25.00 & 4 & 13.33 \\
\hline & 55 and + & 8 & 36.36 & 3 & 37.50 & 11 & 16.67 \\
\hline & Total & 22 & 100.00 & 8 & 100.00 & 30 & 100.00 \\
\hline
\end{tabular}

Table 2 - Distribution of the individuals with Temporomandibular Disorders, according to gender and age group in the group that received dental treatment only, Ribeirão Preto - SP, 2008

\begin{tabular}{|c|c|c|c|c|c|c|c|}
\hline \multirow{3}{*}{ Group } & \multirow{3}{*}{$\begin{array}{c}\text { Age } \\
\text { (years) }\end{array}$} & \multicolumn{4}{|c|}{ Gender } & \multirow{2}{*}{\multicolumn{2}{|c|}{ Total }} \\
\hline & & \multicolumn{2}{|c|}{ Female } & \multicolumn{2}{|c|}{ Male } & & \\
\hline & & $\mathrm{n}$ & $\%$ & $\mathrm{n}$ & $\%$ & $n$ & $\%$ \\
\hline \multirow{6}{*}{ Control } & 18 to 24 & 10 & 37.04 & 0 & 0.00 & 10 & 33.33 \\
\hline & 25 to 34 & 8 & 29.63 & 1 & 33.33 & 9 & 30.00 \\
\hline & 35 to 44 & 1 & 3.70 & 0 & 0.00 & 1 & 3.33 \\
\hline & 45 to 54 & 7 & 25.93 & 1 & 33.33 & 8 & 26.67 \\
\hline & 55 and + & 1 & 3.70 & 1 & 33.33 & 2 & 6.67 \\
\hline & Total & 27 & 100.00 & 3 & 100.00 & 30 & 100.00 \\
\hline
\end{tabular}

The age group most affected by TMD was that of 50 to 70 years in the experimental group, representing $36.67 \%$, and that of 18 to 24 years in control group, with $33.33 \%$.
The median values of the SF-36 scores in each domain, in both groups, at the beginning and end of the treatment are presented in Table 3.

Table 3 - Median scores of the SF-36 in each domain in both groups, Ribeirão Preto-SP, 2008

\begin{tabular}{lcccc}
\multicolumn{1}{c}{ Domains } & Experimental & \multicolumn{2}{c}{ Median score } & Control \\
& Beginning & End & Beginning & End \\
\hline Functional Capacity & 62.5 & 87.5 & 85.0 & 87.5 \\
Physical Aspects & 12.5 & 100 & 50.0 & 25.0 \\
Pain & 41.0 & 62.0 & 56.0 & 62.0 \\
General Health Status & 56.0 & 72.0 & 68.5 & 67.0 \\
Vitality & 45.0 & 60.0 & 50.0 & 52.5 \\
Social Aspects & 50.0 & 75.0 & 62.5 & 68.7 \\
Emotional Aspects & 33.1 & 66.6 & 33.3 & 33.3 \\
Mental Health & 52.0 & 66.0 & 56.0 & 56.0 \\
\hline
\end{tabular}


The Functional Capacity (FC) domain evaluates the presence of physical limitations and how they affect the physical capacity of the individual. From the median value, it was observed that the experimental group increased from $62.5 \%$ to $87.5 \%$, while the control group increased from $85 \%$ to $87.5 \%$.

The Physical Aspects (PA) domain, which evaluates limitations in the form and amount of work, increased in the experimental group from $12.5 \%$ to $100 \%$, while the control group presented a reduction from $50 \%$ to $25 \%$.

The domain related to pain is responsible for evaluating its intensity and how it affects activities of daily living. An increase was observed in both groups in this domain, with the experimental group increasing from $41 \%$ to $62 \%$ and the control group $56 \%$ to $62 \%$.

The General Health Status (GHS) domain evaluates the perceptions of the individual regarding his/her health, with an increase observed in the experimental group from $56 \%$ to $72 \%$ and a decrease in the control group from $68.5 \%$ to $67 \%$.

Vitality (VIT) is evaluated from the level of energy and fatigue of each individual. An increase in the experimental group was observed from $45 \%$ to $60 \%$ and in the control group from $50 \%$ to $52.5 \%$.

The Social Aspects (SA) domain evaluates the participation of the individual in social groups and whether this is compromised by any health problems, with the experimental group presenting an improvement from $50 \%$ to $75 \%$ in this domain and the control group from $62.5 \%$ to $68.7 \%$.

The Emotional Aspects (EA) domain evaluates limitations in the form and amount of work and how this affects the activities of daily living of the patient. Based on the table, it can be observed that the experimental group presented an improvement from $33.1 \%$ to $66.6 \%$, while the control group remained at the same value of $33.3 \%$ before and after treatment.

The final domain of Mental Health (MH) is evaluated through the presence of distress and psychological well-being, with the experimental group presenting positive data, increasing from $52 \%$ to $66 \%$, while the control group remained at the same value of $56 \%$.

Table 4 presents the comparisons between the two measurements in each domain of the SF-36, in the two groups, through the Wilcoxon test.

Table 4 - Comparison between the two measurements in each domain of the SF-36, in the two groups, through the Wilcoxon test, Ribeirão Preto-SP, 2008

\begin{tabular}{|c|c|c|c|c|}
\hline Group & Domains & $z$ & $P(z)$ & Conclusion ( $5 \%$ level) \\
\hline \multirow{8}{*}{ Experimental } & Initial FC $x$ final FC & 4.73 & .000 & Initial FC $<$ final FC \\
\hline & Initial PA x final PA & 4.41 & .000 & Initial $P A<$ final $P A$ \\
\hline & Initial pain $x$ final pain & 4.40 & .000 & Initial pain < final pain \\
\hline & Initial GHS x final GHS & 2.17 & .030 & Initial GHS < final GHS \\
\hline & Initial VIT x final VIT & 3.70 & .000 & Initial VIT < final VIT \\
\hline & Initial SA $x$ final SA & 2.72 & .006 & Initial $S A<$ final $S A$ \\
\hline & initial $E A x$ final $E A$ & 3.06 & .000 & initial $E A<$ final $E A$ \\
\hline & Initial MH x final $\mathrm{MH}$ & 4.27 & .000 & Initial $\mathrm{MH}<$ final $\mathrm{MH}$ \\
\hline \multirow{8}{*}{ Control } & Initial FC $x$ final FC & 0.96 & .337 & Initial FC = final FC \\
\hline & Initial PA $x$ final PA & 1.37 & .170 & Initial $P A=$ final $P A$ \\
\hline & Initial pain x final pain & 1.98 & .047 & Initial pain < final pain \\
\hline & Initial GHS x final GHS & 0.87 & .382 & Initial GHS = final GHS \\
\hline & Initial VIT x final VIT & 0.05 & .957 & Initial VIT = final VIT \\
\hline & Initial SA $x$ final SA & 0.88 & .381 & Initial $S A=$ final $S A$ \\
\hline & initial $E A x$ final $E A$ & 1.07 & .282 & initial $E A=$ final $E A$ \\
\hline & Initial MH x final MH & 0.13 & .896 & Initial $\mathrm{MH}=$ final $\mathrm{MH}$ \\
\hline
\end{tabular}

Note: FC: functional capacity; PA: physical aspects; GHS: general health status; VIT: Vitality; SA: social aspect; EA: emotional aspect; MH: mental health. 
Through this table, it can be concluded that there were statistically significant differences in all areas for the experimental group ( $\mathrm{p}<.05)$, however, the in control group the only statistically significant difference was in the pain domain $(\mathrm{p}=.04)$ (Table 4$)$.

\section{Discussion}

According to Oliveira (8) the causes of TMD are variable and dependent on the age of the population, suggesting that between 15 and 40 years of age they are due to myogenic factors and when the age is over 40 years this factor is found to be related to arthrogenic factors.

Over $70 \%$ of healthy individuals have at least one TMD sign, however, only 5-7\% of them seek treatment, with this disorder more prevalent in women aged 20 to 50 years, a fact that is similar to the results found in this study (7).

When comparing the results between the groups, improved scores in the SF-36 questionnaire can be observed in the group that received physical therapy (experimental group).

In this study the SF-36 was shown to be a tool of simple application that was easy to understand by the volunteers, minimizing the influence of the examiner on the patients and consequently on their responses.

Patients with TMD usually present some limitations in their daily activities, which are largely responsible for the decrease in QoL of these individuals $(21,22)$.

The evaluation of quality of life, initially, was to complement analyzes of survival, adding to the other clinical parameters. Currently, this evaluation has expanded its scope by integrating analyzes of costeffectiveness. Quality of life is an expression rooted in professional practice and increasingly present in specialized publications. This term has been used in articles that apply validated questionnaires or not for its measurement, or in articles that simply discuss the impact of a particular procedure or intervention $(23,24)$.

A retrospective study by Matta and Honorato (25), in which the physical therapy intervention in TMD patients treated at a public health service in Campinas-SP was evaluated, showed that the interdisciplinary approach is a necessity, and that physical therapy, when carried out comprehensively, without being restricted to the isolated use of therapeutic modalities, can significantly help in controlling the symptoms manifested by the TMD, thus promoting a better quality of life for these individuals.

A study by Oliveira et al. (3), observing the impact of pain in subjects with TMD, through the McGill pain questionnaire (Br-MPQ), in which 22 subjects diagnosed with TMD received physical therapy, concluded that the pain in TMD presented a negative impact on the QoL of the individuals and that the questionnaire was effective, although not specific. This procedure was similar to that of the present study, in which a non-specific questionnaire (SF-36) was also used for the evaluation of quality of life and was shown to be capable of being sensitive to changes promoted by the performance of a physical therapy protocol.

Various studies have shown the beneficial effects of myofascial therapy for improving the pain condition of TMD patients (26). Regarding the use of therapeutic ultrasound, it was found that this can be safely used on the TMJ, without risk of overheating or damage to the teeth or their fillings (16).

According to Feine et al. (27) it is necessary to offer patients treatment capable of reducing their limitations, as well as the discomfort caused by pain, aiming to improve their quality of life. In this context, physical therapy can be an effective resource in cases of TMD, especially for those in which the pain persists (28).

The literature focuses on the efficacy of the association of therapeutic exercises and electrotherapy in the treatment of myogenic TMD, resulting in the normalization of the range of mandibular motion, elimination of pain and inflammation, and elimination of the restrictions to the mandibular function (25).

It is considered that the evaluation of quality of life to measure the effectiveness of a physical therapy protocol is necessary to enable the professional to monitor the belief of the patient in the therapeutic planning, considering the patient as an integral being. Thus, the analysis of the quality of life becomes central to adaptations of the therapeutic strategy adopted in accordance with the requirements of the patient (29).

The interdisciplinary treatment of multifactorial diseases is a consensus among authors, however, is not always consistent with reality and, despite the positive results observed in clinical practice, research is still lacking on the role of the physical therapist in TMD. 
This study presents limitations related to the control of the presence of other comorbidities that could affect the quality of life of these subjects and the disparity in the age groups of the groups studied.

Despite the positive results found in the literature, a limiting factor in the analysis of the majority of studies on manual therapy is the frequent absence of an explicit description of the focus techniques, taking into account that the terms manual therapy, mobilization and manipulation are generic and can include many forms of passive movement, which could constitute a methodological weaknesses in the present study.

Few studies on TMD evaluate the quality of life, which could demonstrate the efficacy of physical therapy in chronic conditions. Filling this gap is necessary for the development of therapeutic, educational, promotion and prevention programs directed toward behavioral changes consistent with the concept of integral health.

Therefore, conducting further research with a larger number of subjects evaluated through the same instruments is suggested in order to confirm the results presented.

\section{Conclusion}

From the results obtained, it was concluded that the application of a physical therapy protocol was able to improve the quality of life of patients with TMD.

\section{References}

1. Rizzatti BCM, Arana ARS, Cunha Jr AC, Morais ABA, Gil IA. Avaliação diária da dor na desordem temporomandibular: caso clínico. Rev ABO Nac. 2000;8(3):171-5. Portuguese.

2. Pinto MVM, Silva ALS, Barbosa LG, Santos AG, Felício Jr J, Maria J, et al. Estudo do impacto psicossocial causado pela dor, em portadores de disfunção temporomandibular. Fisioter Bras. 2006;7(6):423-8. Portuguese.
3. Oliveira AS, Bermudez CC, Souza RA, Freitas CMS, Castro CES, Bérzin F. Avaliação multidimensional da dor em portadores de desordem temporomandibular utilizando uma versão brasileira do Questionário McGill de Dor. Rev Bras Fisioter. 2003;7(2):151-8. Portuguese.

4. Pedroni CR, Oliveira AS, Guaratini MI. Prevalence study of signs and symptoms of temporomandibular disorders in university students. J Oral Rehabil. 2003;30(3):283- 9.

5. Ritzel CH, Diefenthaeler F, Rodrigues AM, Guimarães ACS, Vaz MA. Temporomandibular joint dysfunction and trapezius muscle fatigability. Rev Bras Fisioter. 2007;11(5):333-9.

6. Piozzi R, Lopes FC. Desordens temporomandibulares: aspectos clínicos e guia para a Odontologia e Fisioterapia. JBA. 2002;2(5):43-7. Portuguese.

7. Serafim F, Teodoroski RCC. Laser arseneto de gálio (Ga-As) no tratamento das algias provocadas pela disfunções temporomandibular: estudo piloto. Fisioter Bras. 2004;4(1):32-8. Portuguese.

8. Biasotto-Gonzalez DA. Abordagem interdisciplinar das disfunções temporomandibulares. São Paulo: Manole; 2005. Portuguese.

9. Kato MT, Kogawa EM, Santos CN, Conti PCR. TENS and low-level laser therapy in the management of temporomandibular disorders. J Appl Oral Sci. 2006;14(2):130-5.

10. Fricton JR, Dubner R. Dor Orofacial e Desordens Temporomandibulares. São Paulo: Santos Editora; 2003. Portuguese.

11. Mynaio MCS, Hartz ZMA, Buss, PM. Qualidade de Vida e saúde: um debate necessário. Cienc Saude Colet. 2000;5(1):7-19.

12. Santos SR, Santos IBC, Fernandes MG, Henriques MERM. Qualidade de Vida do Idoso na comunidade: aplicação da escala de Flanagan. Rev Lat Am Enfermagem. 2002;10(6):75764. Portuguese.

13. Tedeschi-Marzola F, Pasqual-Marques A, Marzola C. Contribuição da Fisioterapia para a Odontologia nas Disfunções da Articulação Temporomandibular. Rev Odonto Cienc. 2002;17(36):11934. Portuguese. 
14. Resolução CNS/MS nô196, de 10 de outubro de 1996. Aprova diretrizes e normas regulamentadoras de pesquisa envolvendo seres humanos. Diário Oficial da União: Brasília. 1996;201:2182; Seção 1. Portuguese.

15. Ciconelli RM, Ferraz MB, Santos W. Tradução para a língua portuguesa e validação do questionário genérico de avaliação de qualidade de vida SF-36. Rev Bras Reumatol. 1998;39(3):14350. Portuguese.

16. Salome W, Gann N, Jones D. Heating effects of ultrasound applied to extracted molar. Is it safe to apply ultrasound to the temporomandibular joint? Physiotherapy. 2002;88:167-70.

17. McNeely ML, Armijo OS, Magee DJ. A systematic review of the effectiveness of physical therapy interventions for temporomandibular disorders. Phys Ther. 2006;86:7110-25.

18. 18. La Touche R, Fernández-de-las-Peñas C, Fernández-Carnero J, Escalante K, AnguloDíazParreño S, Paris-Alemany A, et al. The effects of manual therapy and exercises directed at the cervical spine on pain sensitivity in patients with myofascial temporomandibular disorders. J Oral Rehabil. 2009;36:644-52.

19. Steenks MA, Wijer A. Disfunções da Articulação Temporomandibular do ponto de vista da Fisioterapia e da Odontologia: Diagnóstico e Tratamento. São Paulo: Santos Editora; 1996. Portuguese.

20. Siegel S, Castellan Jr NJ. Estatística Não-Paramétrica para Ciências do Comportamento. Porto Alegre (Brazil): Arfmed; 2006. Portuguese.

21. Oliveira AS, Bermudez CC, Souza RA, Souza CMF, Dias EM, Castro SCE, et al. Impacto da dor na vida de portadores de disfunção temporomandibular. J Appl Oral Sci. 2003;11(2):138-43.

22. 22. Seidl EM, Zannon F, Costa CML. Quality of life and health: conceptual and methodological issues. Cad Saude Publica. 2004;20(2):580-8.
23. Guimarães GV, D'Avila V, Bocchi EA, Carvalho VO. Norepinephrine remains increased in the sixminute walking test after heart transplantation. Clinics (Sao Paulo). 2010;65(6):587-91.

24. Steiner ML, Fernandes CE, Strufaldi R, Azevedo LH, Stephan C, Pompei LM, et al. Accuracy study on "Osteorisk": a new osteoporosis screening clinical tool for women over 50 years old. Sao Paulo Med J. 2008;126(1):23-8.

25. Matta MAP, Honorato DC. Uma abordagem fisioterapêutica nas desordens temporomandibulares: estudo retrospectivo. Rev. Fisioter. Univ. Sao Paulo. 2003;10(2):77-83. Portuguese.

26. Felício CM, Melchior MO, Ferreira CL, Silva MA. Otologic symptoms of temporomandibular disorders and effect of orofacia myofunctional therapy. Cranio. 2008;26:118-25.

27. Feine JS, Widmer CG, Lund JP. Physical therapy: a critique. Oral Surg Oral Med Oral Pathol Oral Radiol Endod. 1997;83(1):123-7.

28. Michelotti A, De Wijer A, Steenks M, Farella M. Home-exercise regimes for the management of non-especific temporomandibular disorders. J Oral Rehabil. 2005;32:779-85.

29. Borges MC, Borges CS, Silva AGJ, Castellano LRC, Cardoso FAG. Avaliação da qualidade de vida e do tratamento fisioterapêutico em pacientes com cervicalgia crônica. Fisioter Mov. 2013;26(4):873-81.
Received in 06/08/2014 Recebido em 08/06/2014

Approved in 10/16/2015 Aprovado em 16/10/2015 